\title{
Discovery of the Critically Endangered annual killifish Austrolebias wolterstorffi (Ahl, 1924) (Cyprinodontiformes: Rivulidae) in Lagoa do Peixe National Park, Rio Grande do Sul, southern Brazil
}

\author{
L.E.K. Lanés ${ }^{1} \&$ L. Maltchik ${ }^{2}$ \\ 1,2 Laboratory of Ecology and Conservation of Aquatic Ecosystems, University of Vale do Rio dos Sinos (UNISINOS). Av. Unisinos \\ 950, Bairro Cristo Rei, CEP 93022-000, São Leopoldo, Rio Grande do Sul, Brazil. \\ Email: ${ }^{1}$ lelanes@gmail.com, ${ }^{2}$ maltchik@unisinos.br
}

\begin{abstract}
This paper documents the discovery of the rare and Critically Endangered annual killifish Austrolebias wolterstorffi in temporary wetland of Lagoa do Peixe National Park, an important conservation unit of southern Brazil protected under the Ramsar Convention and recognized Biosphere Reserve.
\end{abstract}

Keywords: Annual fish, Cynolebiasinae, endemic, freshwater, Neotropics, protected areas, Ramsar sites, restricted-range fishes, threatened species, wetlands.

The neotropical aplocheiloid genus Austrolebias Costa comprises 40 small annual killifishes endemic to South America, distributed in southern Brazil, southern Bolivia, Paraguay, Uruguay and northeastern Argentina (Costa 2010). Their highest diversity occurs in Uruguay and southern Brazil, where several distinct species may be found sympatric or syntopic. Austrolebias populations

Date of publication (online): 26 October 2010

Date of publication (print): 26 October 2010

ISSN 0974-7907 (online) | 0974-7893 (print)

Editor: Carlos Alberto S de Lucena

Manuscript details:

Ms \# 02499

Received 02 June 2010

Final revised received 17 August 2010

Finally accepted 02 September 2010

Citation: Lanés, L.E.K. \& L. Maltchik (2010). Discovery of the critically endangered annual killifish, Austrolebias wolterstorffi (Ahl, 1924) (Rivulidae: Cyprinodontiformes) in Lagoa do Peixe National Park, Rio Grande do Sul, southern Brazil. Journal of Threatened Taxa 2(11): 12821285

Copyright: (c) L.E.K. Lanés \& L. Maltchik2010. Creative Commons Attribution 3.0 Unported License. JoTT allows unrestricted use of this article in any medium for non-profit purposes, reproduction and distribution by providing adequate credit to the authors and the source of publication.

Acknowledgements: This research was supported by funds from UNISINOS (02.00.023/00-0) and CNPq (52370695.2). Luis Esteban Krause Lanés has scholarship masters of the CNPq and Leonardo Maltchik holds a Brazilian Research Council - CNPq Research Productivity grant. The material was obtained under MMA/BAMA/ICMBio permits (185761 ). This manuscript was improved by the comments of two anonymous reviewers.

\section{OPEN ACCESS | FREE DOWNLOAD @C (i) ৫}

live in shallow temporary wetlands formed close to rivers, streams and lagoons during the rainy season, and die off when the pools dry (Costa 2003, 2006). Their eggs survive the dry season and hatch after the next rainy season begins.

The genus Austrolebias has recently been redefined phylogenetically by Costa (2006), including the species previously referred to the genus Megalebias Costa. Subsequently the genus Austrolebias was divided into subgenera (Costa 2008), according to clades defined in Costa (2006). Accordingly the subgenus Megalebias which has the same general geographic range as Austrolebias, comprises five valid species: Austrolebias cheradophilus (Vaz-Ferreira, Sierra de Soriano \& Scagliade-Paulete, 1964), Austrolebias elongatus (Steindachner, 1881), Austrolebias monstrosus (Huber, 1995), Austrolebias prognathus (Amato, 1986), and Austrolebias wolterstorffi (Ahl, 1922). They can reach a large size (about 70-120 mm SL), making some the largest among the family Rivulidae (Costa 1998, 2001). These large species are generally rarer than smaller species that are often abundant in their habitats (Costa 2009), probably due to increased energy demand as a function of larger body size (Laufer et al. 2009; Arim et al. 2010).

Austrolebias wolterstorffi (Image 1) the type-species of the Megalebias subgenus is a medium size species (compared with other species of rivulid fishes) reaching about $78 \mathrm{~mm}$, endemic to the Laguna dos Patos hydrographic system and adjacent coastal drainages in southern Brazil and eastern Uruguay. The species feeds mainly on mollusks and is the most specialized of the moluscivorous Austrolebias (Costa 2009). Austrolebias wolterstorffi is considered Critically Endangered by the red books of threatened fauna of Rio Grande do Sul State (Reis et al. 2003) and Brazil (Rosa \& Lima 2008), due to the extensive alteration and loss of wetlands in that region, through anthropogenic activities, especially agriculture. The species is considered vulnerable to developments of forestation with exotic species (e.g. Eucalyptus, Acacia and Pinus) (ZAS 2007).

According to previous studies the record of $A$. wolterstorffi closest to the Lagoa do Peixe National Park 


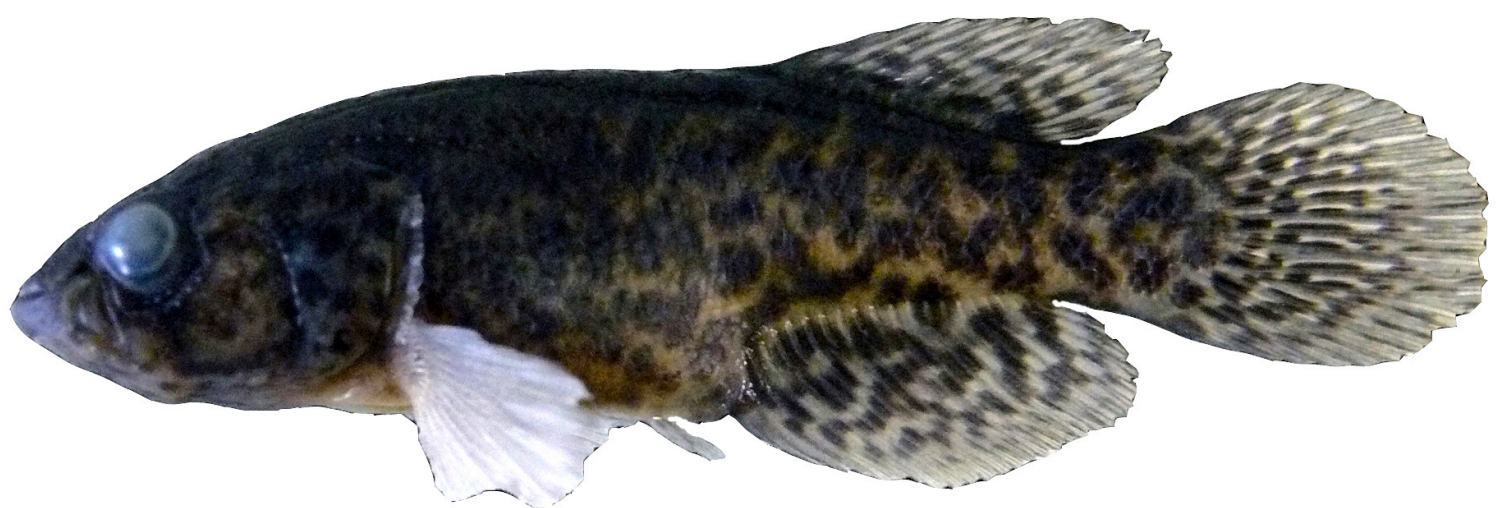

Image 1. Austrolebias wolterstorffi (46.35 SL; MCP 44520) collected from Lagoa do Peixe National Park (LPNP).

was for the São Caetano locality, more than $100 \mathrm{~km}$ of protected area (see the map in Costa 2006). This paper documents the discovery of the species in Lagoa do Peixe National Park and presents recommendations for its conservation in southern Brazil.

Material examined: A female (46.35 SL) was captured on 28 June 2008 in shallow $(33.17 \pm 5.16 \mathrm{~cm}$ depth) palustrine temporary wetland, 31006'55"S \& $50^{\circ} 50^{\prime} 57^{\prime \prime} W$ (Image 2), during a field trip of a research project conducted by the Laboratory of Ecology and Conservation of Aquatic Ecosystems, University of Vale do Rio dos Sinos (UNISINOS). The purpose of the project was to establish the diversity and distribution of annual fishes in Lagoa do Peixe National Park (Fig. 1). Water samples revealed the following parameters: $\mathrm{pH}: 6.52 \pm 0.1$; dissolved oxygen: $9.36 \pm 0.91 \mathrm{mg} / \mathrm{l}$; conductivity: $41.17 \pm 10.83 \mathrm{mS}$; and water temperature: $15.69 \pm 0.38{ }^{\circ} \mathrm{C}$. The specimen collected by hand net (D-shaped, $30 \mathrm{~cm}$ width) was euthanized with a lethal dose of phenoxyethanol, fixed in situ with $10 \%$ formalin and later transferred to $70 \%$ ethanol. Measurements were made with an electronic digital caliper reading to the nearest $0.01 \mathrm{~mm}$, and material was vouchered in collections of fishes of Museu de Ciências e Tecnologia da Pontifícia Universidade Católica do Rio Grande do Sul (MCP 44520). The material was identified based on Costa (2006).

Diagnosis: According to Costa (2006), A. wolterstorffi is distinguished from the remaining species of the Megalebias subgenus by having fewer scales in longitudinal (31-35 vs. 50-75), minute contact organs on uppermost pectoral-fin ray in males (prominent contact organs on most pectoral-fin rays), and a greater number of branchiostegal rays (7 vs. 6).

Austrolebias wolterstorffi is considered a restrictedrange fish (Nogueira et al. 2010), and there are only two previous records of the occurrence of the species in protected areas of Brazil, both in Rio Grande do Sul state: Delta do Jacuí State Park (Reis et al. 2003) and Private Natural Heritage Reserve of Pontal da Barra (Volcan et al. 2009). Although these populations are theoretically protected, these areas have many conflicts of land use, and growing urbanization threatens the habitats of vulnerable species. Despite presenting a relatively wide area of distribution along the Coastal Plain of Laguna dos Patos hydrographic system (Costa 2006), records of $A$. wolterstorffi in the northern portion of the system, where the species has more representation in ichthyological collections are increasingly rare (Reis et al. 2003). In the south of the Laguna dos Patos, Lanés et al. (2005) documented the occurrence of $A$. wolterstorffi in a private area of municipality of Pelotas, near to Pontal da Barra swamp, and Porciúncula et al. (2006) and Quintela et al. (2007) recorded the species in coastal adjacent drainage to this hydrographic system in Rio Grande municipality, an important wetland located in the industrial district of this city.

The Lagoa do Peixe National Park (LPNP) is the only conservation unit in southern Brazil protected under the Ramsar Convention. The LPNP presents a variety of continental, estuarine and marine wetlands, ensuring the survival of a wide variety of species of several groups

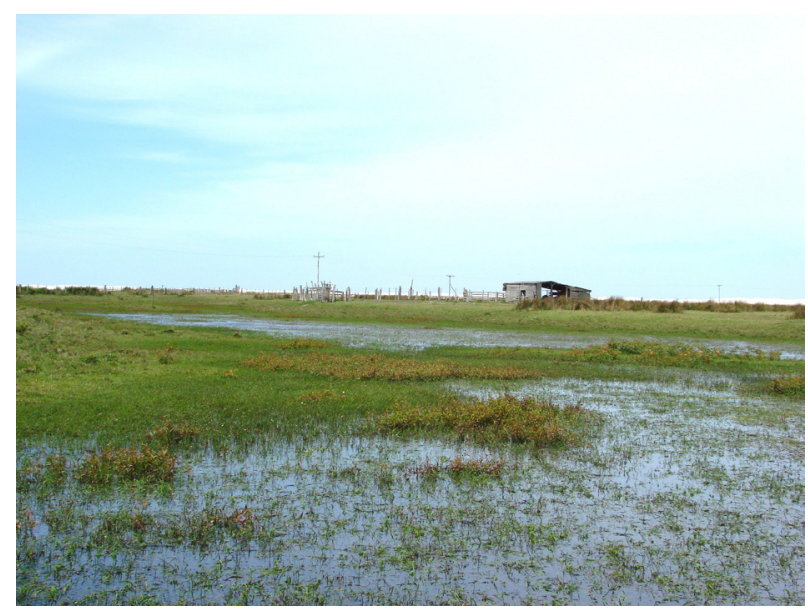

Image 2. Occurence site of Austrolebias wolterstorffi in Lagoa do Peixe National Park. 


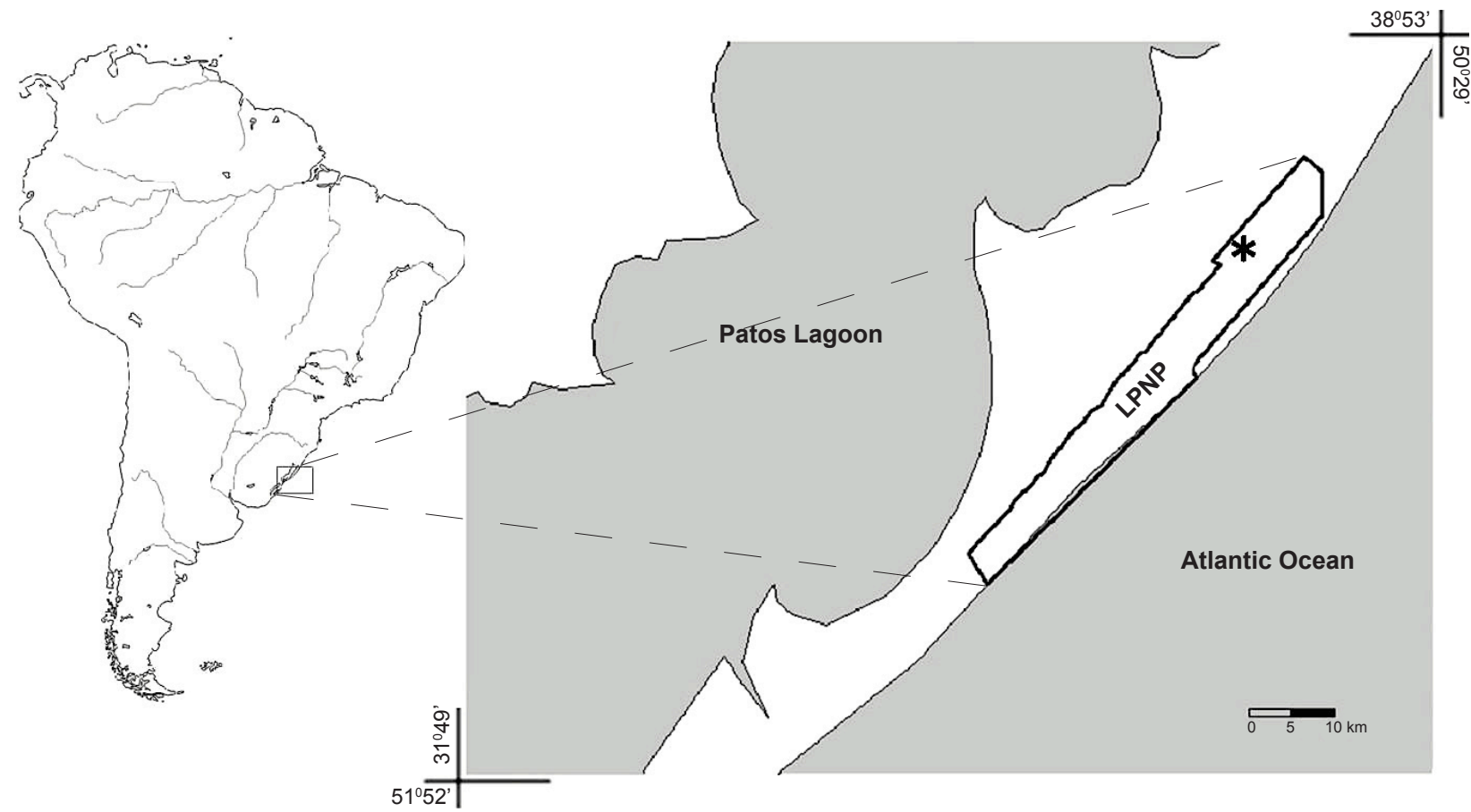

Figure 1. Map showing the present record of Austrolebias wolterstorffi in Lagoa do Peixe National Park, Rio Grande do Sul, southern Brazil.

of organisms. Is recognized Biosphere Reserve and integrates various networks for the protection of waterfowl in the world, such as the Western Hemisphere Shorebird Network. Although several surveys of fish fauna in the area of the park have been made, only recently has killifish diversity has been revealed. Costa \& Lanés (2009) describe Rivulus riograndensis a freshwater non-annual killifish whose type-locality is Pai João swamp in Lagoa do Peixe National Park, and Correa et al. (2009) documented the occurrence of Austrolebias minuano Costa \& Cheffe, 2001 in park area, a species endemic to southern Brazil and threatened in the category "endangered" (Reis et al. 2003; Rosa \& Lima 2008).

Based on the recent records of endangered killifishes, Lagoa do Peixe National Park, traditionally recognized for its biodiversity related to marine and estuarine ecosystems, is recognized now for its importance in the conservation of these endangered species that present restricted distribution and are exclusive of continental wetlands. These are the most threatened ecosystems in southern Brazil, and studies suggest that over $90 \%$ of natural wetlands have been lost (Rolon et al. 2008; Maltchik 2010), especially due to drainage for irrigated rice production (Fontana el al. 2003).

Although the record of $A$. wolterstorffi for LPNP is important, it is required for their conservation and that wetlands of southern Brazil be preserved from agriculture and exotic forestry expansion, since these are the most threatened ecosystems in this region and are habitat to several endemic and endangered species. In addition, studies are needed to assess the population status of $A$. wolterstorffi in protected areas, establish priority areas for conservation, perform bio-ecological research and establish the inclusion of species in the IUCN Red List of Threatened Species. These recommendations apply also for other Austrolebias species endangered and endemic to southern Brazil.

\section{REFERENCES}

Arim, M., S.B. Abades, G. Laufer, M. Loureiro \& P. Marquet (2010). Food web structure and body size trophic position and resource acquisition. Oykos 119: 147-153.

Correa, F., A.M. Garcia, D. Loebmann, M.C. Claudino, R.F. Bastos \& J.P. Vieira (2009). Pisces, Cyprinodontiformes, Rivulidae, Austrolebias minuano (Costa and Cheffe, 2001): new species record at Lagoa do Peixe National Park, state of Rio Grande do Sul, Brazil. Check List 5: 763-766.

Costa, W.J.E.M. (1998). Phylogeny and classification of Rivulidae revisited: evolution and miniaturization of rivulid fishes (Cyprinodontiformes: Aplocheiloidei). Journal of Comparative Biology 3: 32-92.

Costa, W.J.E.M. (2002). Monophyly and phylogenetic relationships of the neotropical annual fish genera Austrolebias and Megalebias (Cyprinodontiformes: Rivulidae). Copeia 4: 916-927.

Costa, W.J.E.M. (2003). Family Rivulidae (South American annual fishes), pp. 526-548. In: Reis, R.E., S.O. Kullander \& C.J.Jr. Ferraris (eds). Check List of The Freshwater Fishes of South and Central America. Edipucrs, Porto Alegre, 729pp.

Costa, W.J.E.M. (2006). The South American annual killifish genus Austrolebias (Teleostei: Cyprinodontiformes: Rivulidae): phylogenetic relationships, descriptive morphology and taxonomic revision. Zootaxa 1213: 1-162. 
Costa, W.J.E.M. (2008). Catalog of Aplocheiloid Killifishes of The World. Reproarte, Rio de Janeiro, 120pp.

Costa, W.J.E.M. (2009). Trophic radiation in the South American annual killifish genus Austrolebias (Cyprinodontiformes: Rivulidae). Ichthyological Explorations Freshwaters 20: 179191.

Costa, W.J.E.M. (2010). Historical biogeography of annua killifish Cynolebiasine inferred from dispersal-vicariance analysis. Journal of Biogeography 37: 1995-2004.

Costa, W.J.E.M. \& L.E.K. Lanés (2009). Rivulus riograndensis, a new aplocheiloid killifish from southern Brazil (Cyprinodontiformes: Rivulidae). Ichthyological Exploration of Freshwaters 20: 91-95.

Fontana, C.S., G.A. Bencke \& R.E. Reis (2003). Livro vermelho da fauna ameaçada de extinção no Rio Grande do Sul. Edipucrs, Porto Alegre, 632pp.

Lanés, L.E.K., M.V. Volcan, G.M. Wallwitz, M.P. Corrêa, M.P. Basilio \& A. Bager (2005). Ocorrência de duas espécies de peixes anuais (Rivulidae) ameaçadas de extinção na área urbana de Pelotas, RS. In: III Simpósio de Áreas Protegidas, Pelotas, 535-539pp.

Laufer, G., M. Arim, M. Loureiro, J.M. Piñero-Guerra, S. Clavijo-Baquet \& C. Fagúndez (2009). Diet of four annual killifishes: an intra and interspecific comparision. Neotropical Ichthyology 7: 77-86.

Maltchik, L., L.E.K. Lanés, C. Stenert \& E.S.F. Medeiros (2010). Species-area relationship and environmental predictors of fish communities in coastal freshwater wetlands of southern Brazil. Environmental Biology of Fishes 88: 25-35.

Nogueira, C., P.A. Buckup, N.A. Menezes, O.T. Oyakawa, T.P. Kasecker, T.P. Kasecker, M.B.R. Neto \& J.M. da Silva (2010). Restrict-range fishes and the conservation of Brazilian freshwaters. Plos One 5: e11390.
Porciuncula, R.A., F.M. Quintela \& D. Loebmann (2006). Pisces, Cyprinodontiformes, Rivulidae, Austrolebias minuano Costa \& Cheffe, 2001 and Megalebias wolterstorffi (Ahl, 1924): new species records at Rio Grande city, Rio Grande do Sul state, Brazil. Check List 2: 44-46.

Quintela, F.M., R.A. Porciuncula, M.V.L. Condini, J.P. Vieira \& D. Loebmann (2007). Composição da ictiofauna durante o período de alagamento em uma mata paludosa da planície costeira do Rio Grande do Sul, Brasil. Pan-American Journal of Aquatic Sciences 2: 191-198.

Reis, R.E., Z.M. Lucena, C.A.S. Lucena \& L.R. Malabarba (2003). Peixes, pp. 117-145. In: Fontana, C.S., G.A. Bencke \& R.E. Reis (eds). Livro vermelho da fauna ameaçada de extinção no Rio Grande do Sul. Edipucrs, Porto Alegre, 632pp.

Rolon, A.S., T. Lacerda, L. Maltchik \& D.L. Guadagnin (2008). The influence of area, habitat and water chemistry on richness and composition of macrophyte assemblages in southern Brazil wetlands. Journal of Vegetation Science 19: 221-228.

Rosa, R.S. \& F.C.T. Lima (2008). Peixes, pp. 8-285. In: Machado A.B.M., G.M., Drummond \& A.P. Paglia (eds). Livro vermelho da fauna brasileira ameaçada de extinção. Ministério do Meio Ambiente, Brasília, 1420pp.

Volcan, M.V., L.E.K. Lanés \& A.C. Gonçalves (2009). Threatened fishes of the world: Austrolebias nigrofasciatus Costa and Cheffe 2001 (Cyprinodontiformes: Rivulidae). Environmental Biology of Fishes 86: 319-320.

Zoneamento Ambiental para Atividade de Silvicultura [ZAS]. (2007). Coordenação: FEPAM. Consultoria Técnica: Biolaw Consultoria Ambiental e Fundação Zoobotânica do Rio Grande do Sul, 305pp. 